\title{
The Role of Indigenous Knowledge in Conservation Agriculture: The Case of Lare District in Gambella Region, Ethiopia
}

\author{
Eshetu Nigussie $^{1} \quad$ Tamene Betebo $^{2} \quad$ Jemal Yousuf $^{3}$ \\ 1. Department of Rural Development and Agricultural Extension, Gambella University, Ethiopia \\ 2 Department of Rural Development and Agricultural Extension, Wachemo University, Ethiopia \\ 3. PhD (Assistance Professor), Head, Department of Rural Development and Agricultural Extension Haramaya \\ University
}

\begin{abstract}
This study seeks to identify indigenous conservation agriculture practices by conducting key informant survey on 15 households and to analyze factors influencing the probability of using minimum tillage by employing crosssectional survey data collected from 120 households using logit model with.STATA12. The findings revealed that farmers had considerable knowledge about minimum tillage, spacing, and row cropping, intercropping and shifting grazing land were the merits for conservation agriculture. Improper seed rate, absence of farm yard manure as fertilizer and burning of crop residues were demerits. The survey respondents were drawn from Lare district of Nuer Zone in Gambella region. The survey result yields households having greater number of livestock and farm labor, good perception of traditional technology and larger size of land are more likely to utilize minimum tillage. By contrast, households having non-farm activity has a strong and negative effect on minimum tillage. This suggests that policy makers can scale up the use of minimum tillage by facilitating a medium of knowledge transfer from elders to youths as age is positively correlated with livestock holding, number of farm labor and land holding as well as minimum tillage, by diffusing the importance of conservation agriculture and by creating awareness about the benefits of diversifying economic activities to split risks by using their resource abundance and endowment advantages.
\end{abstract}

Keywords: indigenous knowledge, conservation agriculture, minimum tillage, logit model

DOI: $10.7176 /$ ISDE/11-1-02

Publication date: January $31^{\text {st }} 2020$

\section{INTRODUCTION}

As defined by different literatures the names minimum tillage, zero tillage, no tillage, direct drilling, conservation agriculture, and conservation tillage are some of the commonly used names, (FAO,2011b), (WLA, 2014). In principle key-elements of conservation agriculture (CA) are minimal soil disturbance (minimum or no-tillage), stubble retention, and the implementation of viable crop rotations. The roots of the origins of CA lie more in the farming communities than in the scientific community, and its spread has been largely farmer-driven (FASR, 2012). CA represents the core components of a new alternative paradigm for the $21^{\text {st }}$ century and calls for a fundamental change in production system thinking. It is counterintuitive, novel and knowledge and management intensive.

It has been well understood that CA provides environmental services such as contributing to atmospheric carbon sequestration, preserving biodiversity, managing watersheds and preventing soil erosion (Fowler et al, 2001). Communities and societies can also benefit from the adoption of CA through improved food and water security, more reliable water supplies (Fowler et al, 2001) and protection of ecosystem services (Kassam et al, 2008). In the context of labour constraints such as due to HIV/AIDS and rural migration to towns and cities, less labour intensive CA systems can leave farmers with more time to dedicate to other activities (FAO, 2009). According to FAO 2011 the growth of the area under CA has been especially significant in South America where the MERCOSUR countries (Argentina, Brazil, Paraguay and Uruguay) are using the system on about $70 \%$ of the total cultivated area. More than two thirds of no-tillage practiced in MERCOSUR is permanently under this system, this means once started the soil is never tilled again. In other words $45 \%$ of the total global area under CA is in South America, 32\% in the United States of America and Canada, 14\% in Australia and New Zealand and 9\% in the rest of the world including Europe, Asia and Africa.

However, in Africa and specially East Africa, whether or not CA provides benefits for smallholder systems in Africa has been subject to an ongoing debate (Giller et al., 2009). A major criticism is that the socio-economic dimensions of smallholder farms are often insufficiently addressed in existing CA research. For instance, poor farmers lack the resources to purchase expensive inputs, which may or may not be available locally. Greater reliance on hand weeding is likely to increase the workload of women and children. In addition, residue retention usually conflicts in farming systems with livestock, where crop residues are a valued feed, other uses includes its use as fuel, and in construction. During the past time subsistence farmers used shifting cultivation to restore soil fertility. This practice was sustainable at low levels of productivity, when human population density was low. But with population growth, the demand for food has increased. As a consequence the area, duration and frequency of long bush fallows in shifting systems have declined, and permanent cultivation has become increasingly common. 
The intensified land use combined with insufficient manure supply and the world's lowest use of mineral fertilizer (FAO, 2008) has deteriorated soil fertility. This is often aggravated by soil erosion. Crop yields are low even in good seasons as nutrient deficiencies restrict crop responses to available soil water.

In Ethiopia CA best practice package activities were initially promoted by FAO in 1998, among one of the initiatives introduced to abate deterioration of soil and water resources (Matsumoto, 2004). However its adoption was not effective in Ethiopia. This is also holds true in Gambella region, specifically Lare district where smallholder farmers have been indigenously practicing minimum tillage.

Although change has been attempted through different trainings and programs as in the case of villagization program as smallholder farmers are not using draft animals, no or minimum use of commercial farm inputs, small crop land holding size, and practice traditional knowledge of minimum tillage, frequent drought and flood threatened area or water lodging of lowland and high temperature favoring extreme evaporation; change was not effective. Again this condition of the smallholder farmers that the choice of CA would be affected by the socioeconomic, institutional, and geophysical factors.

In general, based on the above debate this study is conducted to direct at (i) identifying indigenous CA practices being used by smallholder farmers, and (ii) investigating the relationship, between farmers' demographic, socio-economic and institutional characteristics and their probability of using minimum tillage.

\subsection{Statement of the Problem}

Ethiopian agriculture is characterized by low productivity attributed mainly to soil degradation and inefficient use of water resources. Almost all of the country's crop farming is operated by smallholder farmers, practicing traditional plough-based activities. It is well documented that conventional farming with frequent ploughing gradually degrades the physical structure and chemical quality of tropical soils (Brady and Weil, 2001). The conventional mode of agriculture through intensive agriculture practices were successful in achieving goals of production, but simultaneously led to degradation of natural resources.

In Gambella region in general and Lare district in particular even though conventional farming with plough based is not practiced by small holder farmers, other various manmade unsustainable management practices such as over grazing, cutting of trees, burning of crop residue, burning of grass, traditional and low input agriculture such as none use of draft animals, non use of commercial inputs, using backward farm implements made the district small holder farmers to produce lower. The long lasting low input agricultural production systems and poor agronomic practices of the small holder farmers have aggravated soil fertility degradation; this has also prompted the expansion of rangelands and farming to marginal and non-cultivable lands of the district. The unsustainable or poor management practices, in turn contributes to environmental foot print and climate change. It has been reported that agriculture is responsible for about $30 \%$ of the total greenhouse gas emissions of $\mathrm{CO}_{2}, \mathrm{~N}_{2} \mathrm{O}$ and $\mathrm{CH}_{4}$ while being directly affected by the consequences of a changing climate (IPCC, 2007). The change in climate also attributes to natural hazards like flood, water lodging, erosion, drought, dry spell and heavy rainfall, which in turn attributes to low productivity of food crop production of small holder farmers of the district (Samson, 2008),(APACC, 2011).

In general the local smallholder farmers' livelihood of Lare district has been affected by natural hazards in the following ways: Flood affected wetland by transporting suspended soil particles from the highland areas and silted on the low wetlands since the slops of most wetlands of the district are flat. This resulted on reducing in both size and volume of wetland areas for crop and range land. More it frequently displaces the residents living near the river banks. Drought is also another impact affecting the wetland areas through evapo-transpiration from the surface of the wetland. This resulted in reducing and disturbs the wetland ecosystem, for crop production and range or forage production by reducing soil moisture due to high temperature and erratic rain fall and furthermore ground water table would be reduced. Rangeland degradation in all the grass land of the district is seasonal, this means during the rainy season there is lash and palatable forage almost everywhere in the district; to the contrary, during the dry season the abundance, succulence and palatability of the grass species will be reduced except the land closer to banks of rivers and swamps. This led to reduce the existing quantity and quality of the grass. The persistent and prolonged drought is also defined as a prolonged absence or marked deficiency of rain fall, when it is by far less than evaporation and accompanied by high temperatures so that the soil loses its potential to retain soil moisture (BOARD, 2010).

To change the low productivity status of agriculture through sustainable environmental protection the regional government introduces different programs and packages that centered the rural peoples. Amongst the principal programs the recent villagization program has been designed as one of the programs to achieve sustainable production in the district. In the villagization program oxen plough training was also one of the focus activities (BOARD, 2010). But this training was not effective in the local farmers' situation, which means, farmers became resistant (did not adopt) the oxen based plow; rather they have kept on using traditional minimum tillage practice. The choice of smallholder farmers between the two types of tillage implies that local farmers have their own socioeconomic, demographic, institutional and geophysical reasons to choose traditional minimum tillage. Nowadays, 
there are various agronomic/technical, socio-economic and environmental problems that can be tackled with CA technologies in both developed and developing countries' after adoption. For instance; restoring the fertility and productivity of soils which have degraded due to the effects of tillage and erosion could be resolved with CA practices. Using the three CA principles of soil cover with organic matter, minimum soil disturbance and diversifying crop rotations the productivity of the land can be improved, which is important for the food security and poverty reduction of the rural poor. The researchers found that CA has contributed to the accumulation of assets held by smallholder farmers in areas of natural, social, financial, human and physical capital; has improved the productivity of land with higher output to input ratios; reduced the necessity to resort to coping strategies as a way of meeting income gaps and increased resilience to shocks and stresses such as periods of drought and low rainfall. (IIRR, 1998 and Benine et al., 2003)

The local farmers' interest and needs of minimum tillage was not yet studied in the district, rather the use of this indigenous practice has been still underestimated, considered as backward and not subjected to change by outsiders. However, the use of IK is gaining increasing attention and its' importance in sustainable development is well-recognized (Kolawole, 2001). In various places in the world, scientists and indigenous people are collaborating to build bridges between modern science and indigenous knowledge, among others, to improve ecological management of a particular district (Reijntjes, 2004). Policy makers and agricultural development planners are beginning to recognize the need to understand indigenous knowledge systems and have shown renewed interest in this type of knowledge (Warren and Rajasekaran 1993).

To this end, the study of indigenous conservation agriculture would be an input for development interventions as the study is aimed at identifying indigenous conservation agriculture practices and its demographic, socioeconomic, and institutional factors influencing farmers' probability of using minimum tillage in Lare district.

\section{RESEARCH METHODLOGY}

\subsection{Description of the Study Area}

Lare is one of the woredas in the Gambela Region of Ethiopia. Part of the Nuer zone, Lare is bordered on the south and east by the Anuak Zone, on the west by the Baro River which separates it from Jikawo, and on the north by the Jikawo River which separates it from South Sudan. Towns in Lare include Kowerneng. The terrain in Lare consists of marshes and grasslands; elevations range from 300 to 400 meters above sea level. A notable landmark is Gambela National Park, which occupies part of the area south of the Baro. At some point between 2001 and 2007, the eastern kebeles of Jikawo were split off to create Lare. Lare woreda is divided into 28 administrative rural kebeles and one town. Korgang town is the administrative center of the district/woreda. It falls under kola agro-climatic zone and expected to get an average annual rainfall from $900-1200 \mathrm{~mm}$ Hence, the mean temperature of the woreda is 310c-350c. The highest monthly temperature is found in March which reaches up to 450c.

Lare woreda is divided into 28 administrative rural kebeles and one town. Korgang town is the administrative center of the district/woreda. It falls under kola agro-climatic zone and expected to get an average annual rainfall from $900-1200 \mathrm{~mm}$ Hence, the mean temperature of the woreda is $310 \mathrm{c}-350 \mathrm{c}$. The highest monthly temperature is found in March which reaches up to $450 \mathrm{c}$.

Based on the 2007 Census conducted by the Central Statistical Agency of Ethiopia (CSA), this woreda has a total population of 31,406, of whom 16,145 are men and 15,261 women; with an area of 685.17 square kilometers, Lare has a population density of 45.84, which is greater than the Zone average of 23.79 persons per square kilometer. While 6,549 or $20.85 \%$ are urban inhabitants, a further 156 or $0.50 \%$ are pastoralists. A total of 5,432 households were counted in this woreda, which results in an average of 5.8 persons to a household, and 5,217 housing units. The majority of the inhabitants were protestant, with $86.81 \%$ of the population reporting they observed this belief, while $7.48 \%$ practiced traditional religions, $2.69 \%$ were Catholic, and $1.79 \%$ of the population practiced Ethiopian Orthodox Christianity.

Lare district is one of the districts that share the characters of Gambella Agropastora (GAG) livelihood zone of the region. The GAG livelihood zone is considered to have high potential for agricultural production but inappropriate farming practices and lack of draft power means that this potential is not yet exploited. Crop production is mainly rain fed with flood recession planting along the major rivers. The dominant soil types are vertisol, loam soil, verticlay and clay loam. There are two rainy seasons in this zone: the Belthod (meher) is the most important season and belmay (belg) short rains are important mainly for the production of green maize and tobacco. The major crops grown both for consumption and sale are maize and sorghum. Tobacco is also cultivated as a cash crop. Rain fed and recession area farming makes it possible to produce maize in two different seasons. Oxen plows are not used in this area and fields must be prepared by hand. Harvesting is the agricultural activity that requires the most labor. Men and women engage in these activities on their own fields- so labor is not usually paid for. Stalk borer, aphids, locust, army worm, crickets, rodents and wild animals (rodent and others) are all pests that affect particularly maize and sorghum.

Cattle, goats and sheep are the main livestock reared. Animals free graze on grasses and browse. Major and minor rivers and ponds are used for watering the livestock both during wet and dry seasons. Cow milk is a major 
source of food and is also sold. Cattle are usually sold at the age of 3-5 years while shoats are sold from 12-18 months. Shoats are slaughtered during the holidays and festivals. Livestock herd size is maintained by replacing animals from within from the herd. Young men look after cattle and children over seven cares for shoats. Other important economic activities include fishing, wild food collection, and grass and firewood sales are also some activities practiced in the district.

\subsection{Sources and methods of Data Collection}

Both qualitative and quantitative types of data were employed for the study of this thesis research. The study used both secondary and primary data sources. The secondary data sources found at the international ,the federal, regional, and zonal and district level of the Governmental organizations (GOs) and None Governmental Organizations (NGOs) used for the study. Among these official baseline data, results of the subject related studies, final reports of the official activities and the results of statistical studies were used in the data gathering processes.

Primary data sources were collected from the sample survey conducted on the house hold, community members. The data collection methods employed was both primary and secondary methods. The primary data collection methods like personal observations, tools such as personal interviews of key informants using semi structured interviews were conducted.

\subsection{Sampling Techniques Quantitative sample}

The survey gathered quantitative data from 120 sample house hold respondents, especially on their demographic, socio-economic and institutional aspects. For the selection of quantitative samples multi-stage sampling technique was employed. First Lare woreda was purposively selected from the 14 regional woredas based on its accessibility to reliable information and transportation facilities. In the second stage 3 PAs namely, Mallow, Teluth, and patwok were selected using lottery method of simple random sampling method from the total of 28 Peasant Associations (PAs) of the district. In the third stage, using proportionate probability sampling (PPS) 120 household farmers were selected from each PAs.

Qualitative sample

For the identification of indigenous CA practices the list of interview questions were prepared in a semi-structured manner where by only discussion topics were designed in advance and specific questions were opened to actual circumstances. To ensure the smooth flow of information between the interviewers and respondents we used an interpreter to translate from Nuer language into English language. For this study fifteen key respondents were selected for the detail open questions from each kebeles. The key respondents assessed were selected in accordance with suggestions by the community in order to include resourceful and elders with long experience. Household interviews were conducted with both women and men, on the field and in their respective homes, at discussions with local enumerators. The interviews were more informal and qualitative than quantitative and based more on the community's reflections than specific measures. The assessment was centered on indigenous agricultural knowledge and techniques mainly related to conservation agriculture in relation to their benefits from economic, environmental and agronomic point of view The interviews were followed by briefings with the local people in order for them to comment on and provide inputs to the findings of the assessment.

\subsection{Method of Data Analysis}

Both quantitative and qualitative data analyzing methods conducted in this study. The qualitative data analysis based on the dada gathered or the variables created during investigation, the reliable social research data analyzing techniques like gathering, data generalization, and verification, checking and editing, were applied. Both descriptive and econometric models applied in the process of data analysis for both qualitative and quantitative types based on its reliability.

The descriptive data analyzing methods employed to assess the situation of demographic, socioeconomic and institutional variables of the study. The specific quantitative methods of data analysis involve tabulation, frequency, percentages, and computation of descriptive statistics such as mean, standard deviation, $\mathrm{t}$-test and proportion $\mathrm{z}$ tests were analyzed for the study.

\subsection{Econometric model specifications}

In estimating the logit model, the dependent variable is use probability, which takes the value of 1 if a household exercise minimum tillage and 0 otherwise. The mathematical formulation of logit model is as follows:

Where, $P_{\mathrm{i}}=$ the probability of use

$$
P_{i}=\frac{e^{Z_{i}}}{1+e^{Z_{i}}}
$$

Where,

$$
Z_{i}=\beta_{o}+\sum_{i=0}^{n} \beta_{i} X_{i}+\varepsilon_{i}
$$


$i=1,2,3,---, \mathrm{n}$

$\beta_{0}=$ Intercept

$\beta=$ Regression coefficients to be estimated

$\varepsilon=\mathrm{A}$ disturbance term, and

$\mathrm{X}_{\mathrm{i}}=$ Characteristics

The probability that a household belongs to non-user is:

$$
\begin{aligned}
& \left(1-P_{i}\right)=\frac{1}{1+e^{Z_{i}}} \\
& \frac{P_{i}}{1-P_{i}}=e^{Z_{i}} \\
& L_{i}=\ln \left(\frac{P_{i}}{1-P_{i}}\right)=Z_{i}=\beta X_{i}+\varepsilon_{i}
\end{aligned}
$$

$\mathrm{L}_{\mathrm{i}}=\mathrm{Log}$ of the odds ratio, which is not only linear in $\mathrm{X}$ but also linear in parameters.

$\mathrm{X}_{\mathrm{i}}=$ Vector of relevant household characteristics and other variables.

\section{Definition of Variables and Working Hypothesis}

Conservation tillage is a dichotomous ( user or non user) type represented by a value of 1 if a farmer used either practicing minimum tillage at least in one of his farms for the last year and a value of 0 otherwise.

Table 1: Definition and units of measurement of the variables

\begin{tabular}{ll}
\hline Variables & Description and measurement \\
\hline Age & Age of house hold (in years) \\
Active labor force in the family & Number of active family Labor forces. \\
Formal education & $\begin{array}{l}\text { Number of formal education levels reached by } \\
\text { household head }\end{array}$ \\
Experience in farming & Farm experience of household in years. \\
Land holding size & Farm size of household in hectare. \\
Livestock holding & Total livestock owned by the farm household in (TLU). \\
Access to credit & Access to credit in which the farmer gets (1, if yes or 0, \\
& otherwise) \\
Contact with extension agents & $\begin{array}{l}\text { Number or frequency of times extension agent } \\
\text { visited/advised farmer in one cropping year }\end{array}$ \\
Participation in non-farm income activities & Participants take 1 or,0 otherwise \\
Information seeking behavior & The frequency of times the farmer seeks to get \\
information. \\
Receiving remittance & $\begin{array}{l}\text { Remittance receivers takes } 1 \text { or 0, otherwise } \\
\text { in km }\end{array}$ \\
Distance to market & Number of training given for household \\
Participation of training & Good perception take 1 or 0,otherwise \\
\hline
\end{tabular}

Source: own projection, 2015

\section{RESULTS AND DISCUSSION}

This section includes four sub headings namely description of sample households characteristics, determinants of use probability of conservation tillage, inferential statistics and identification of indigenous conservation agriculture practices.

\subsection{Description of Sample Households' Characteristics}

A combination of different descriptive statistics was performed on the household data to inform the subsequent empirical data analysis. In Table 3, the means and proportions of sample households' characteristics are presented. The descriptive results show that there were statistically significant differences between users and non-user of minimum tillage. More particularly, the main differences between the two groups of households were observed with respect to livestock holding, age, farm labor, education level and, participation on non-farm activities, access to credit, participation in training, perception of traditional technology, access to remittance, distance to market and land holding. User households had larger size of livestock and land. As expected, user households are elder than those of non-users and have good perception for traditional technology. Non-user Households are relatively educated, and are working more on non-farm activities. 
Table 2: Mean and proportion difference test of sample households by CA utilization

\begin{tabular}{|c|c|c|c|c|}
\hline \multirow[t]{2}{*}{ Variables } & \multicolumn{3}{|l|}{ Mean/proportion } & \multirow{2}{*}{$\begin{array}{l}\text { Mean } \\
\text { difference } \\
\text { test } \\
\text { (t value) }\end{array}$} \\
\hline & $\begin{array}{l}\text { Sample households } \\
\mathrm{N}=(200)\end{array}$ & $\begin{array}{l}\text { use } \\
\text { households } \\
\mathrm{N}=(100)\end{array}$ & $\begin{array}{l}\text { Non-use } \\
\text { households } \\
\mathrm{N}=(100)\end{array}$ & \\
\hline Livestock & 21.93 & 28.11 & 12.33 & $10.49 * * *$ \\
\hline Age & 39.95 & 49.33 & 25.38 & $8.04 * * *$ \\
\hline Farm labor & 3.10 & 3.47 & 2.55 & $3.91 * * *$ \\
\hline Education level & 4.45 & 3.44 & 6.02 & $-2.94 * * *$ \\
\hline Participation on non-farm activities & 0.43 & 0.34 & 0.55 & $-2.31 * *$ \\
\hline Access to credit & 0.32 & 0.38 & 0.21 & $1.98^{* *}$ \\
\hline Extension contact & 1.408 & 1.410 & 1.404 & 0.07 \\
\hline Participation in training & 0.84 & 0.95 & 0.68 & $1.72 * *$ \\
\hline Perception of traditional technology & 0.58 & 0.69 & 0.43 & $2.89^{* * *}$ \\
\hline Information seeking behavior & 0.58 & 0.59 & 0.57 & 0.16 \\
\hline Remittance & 0.47 & 0.52 & 0.38 & $1.48^{*}$ \\
\hline Distance to market & 10.73 & 11.30 & 9.85 & $3.65^{* * *}$ \\
\hline Land holding & 3.59 & 3.84 & 3.19 & $9.37 * * *$ \\
\hline
\end{tabular}

Source: Authors' computation, 2015

$* * *, * *$ and $*$ means significant at the $1 \%, 5 \%$ and $10 \%$ probability levels, respectively.

\subsection{Determinants of Use Probability}

Before using the logit model for hypothesized variables, it is necessary to test the problem of multicolinearity and contingency association among the potential independent variables. For this purpose, Variance Inflation Factor (VIF) test was employed for association among the continuous explanatory variables (see table 4) and contingency coefficients test (see table 5) was employed for dummy variables.

VIF shows how the variance of an estimator is inflated by the presence of multicolinearity (Gujarati, 2003). Once VIF values were obtained the $\mathrm{R}^{2}$ values can be computed using the formula. As a rule of thumb, if the VIF of a variable exceeds 10 , there is multicolinearity. To avoid serious problems of multicolinearity, it is quite essential to omit the variable with value 10 and more from the logit analysis (Gujarati, 2003). Fortunately, there were no continuous explanatory variable whose VIF was greater than 10 and no dummy variables have seen strongly correlated.

Table 3: Multicolinearity test for continuous explanatory variables

\begin{tabular}{lll}
\hline Variable & VIF & $1 / \mathrm{VIF}$ \\
\hline Age & 3.11 & 0.32 \\
Livestock holding & 3.06 & 0.33 \\
Land holding & 1.35 & 0.74 \\
Education level & 1.26 & 0.79 \\
Farm labor & 1.25 & 0.80 \\
Distance to market & 1.21 & 0.83 \\
Extension contact & 1.07 & 0.93 \\
\hline
\end{tabular}

Source: Author's computation, 2015

As shown above in Table 4, the values of the VIF for seven continuous variables were found to be small (i.e VIF values less than 10) indicating the data have no serious problem of multicolinearity. As a result, all the seven continuous explanatory variables were retained and entered into the binary logistics analysis.

Similarly, the contingency coefficient (see table 5 below), which measures the association between various discrete variables based on the Chi-square, were computed in order to check the degree of association among the discrete explanatory variables or the existence of contingency coefficients. The decision rule for contingency coefficients states that when its value approaches 1 , there is a problem of association between the discrete variables, i.e., the values of contingency coefficients ranges between 0 and 1 , with zero indicating no association between the variables and the values close to 1 , indicating a high degree of association.

Based on the contingency coefficient results, the computation (Table 5) reveals that there was no problem of association among the discrete explanatory variables. Hence, after screening of the best variables among the hypothesized variables multicolinearity problems were checked for both continuous and discrete variables as indicated above in Table 4 and 5, respectively. Accordingly there was no multicolinearity problem in both cases. 
Table 4: Contingency coefficient for dummy variables

\begin{tabular}{|c|c|c|c|c|c|c|}
\hline & $\begin{array}{l}\text { Farm } \\
\text { labor }\end{array}$ & $\begin{array}{l}\text { Participation on } \\
\text { non-farm } \\
\text { activities }\end{array}$ & $\begin{array}{l}\text { Access } \\
\text { to credit }\end{array}$ & $\begin{array}{l}\text { Participation } \\
\text { in training }\end{array}$ & $\begin{array}{l}\text { Perception of } \\
\text { traditional } \\
\text { technology }\end{array}$ & $\begin{array}{l}\text { Information } \\
\text { seeking } \\
\text { behavior }\end{array}$ \\
\hline Farm labor & 1.00 & & & & & \\
\hline Participation on & -0.03 & 1.00 & & & & \\
\hline $\begin{array}{l}\text { non-farm } \\
\text { activities }\end{array}$ & 0.71 & & & & & \\
\hline \multirow[t]{2}{*}{ Access to credit } & 0.06 & -0.04 & 1.00 & & & \\
\hline & 0.51 & 0.65 & & & & \\
\hline Participation in & 0.19 & 0.05 & 0.08 & 1.00 & & \\
\hline training & 0.04 & 0.57 & 0.37 & & & \\
\hline Perception of & 0.09 & -0.13 & 0.14 & -0.01 & 1.00 & \\
\hline $\begin{array}{l}\text { traditional } \\
\text { technology }\end{array}$ & 0.32 & 0.16 & 0.13 & 0.94 & & \\
\hline Information & -0.03 & 0.15 & 0.04 & 0.03 & -0.13 & 1.00 \\
\hline $\begin{array}{l}\text { seeking } \\
\text { behavior }\end{array}$ & 0.70 & 0.11 & 0.65 & 0.74 & 0.74 & \\
\hline
\end{tabular}

Source: Author's own computation, 2015

After checking of multicolinearity problems, analysis of model was conducted. Thirteen independent variables were included in the model. These are age of farm house hold head, educational level of the household head, number of farm labour forces, land holding, livestock holding, distance to market, access to credit and agricultural extension contact. These variables were selected on the basis of the objectives of the study and related literatures.

This section presents the results of the logistic regression model. As indicated earlier, the dependent variable in this model is a binary variable indicating whether the household was a user of minimum tillage. The model is estimated with STATA 12 statistical software package. In the estimation data from the two groups; namely, user and non-user households were pooled such that the dependent variable takes a value 1 if the household was user and 0 otherwise.

In order to get the most preferred equation different model specification can be employed. The number and sign of key variables and accuracy of the whole model are important parameters used as selection criterion (Abebaw et al., 2010). If a given equation comes up with significant and expected signs to key variables, and has a better accuracy, measured by relatively higher pseudo- $\mathrm{R}^{2}$, that model can be considered as preferred specification. This can be seen by adding and eliminating different variables in the specified binary logit model. However, the selection of these variables must be based on economic theory and previous empirical studies, and only relevant variables related to the intervention and outcome should be considered (Heckman et al., 1997). A valid equation requires that the covariates are exogenous and unaffected by the dependent variable.

Table 4 shows the estimation results of the logit model. The estimated model appears to perform well for our intended exercise. The pseudo-R2 value is 0.175 . The pseudo indicates how well the repressors' explain the use probability.

Looking into the estimated coefficients, the results indicate that use probability is significantly influenced by five explanatory variables. Livestock holding, farm labor force, perception of traditional technology and land holding is found to have strong and positive relationship with household use probability. By contrast, household participation in non-farm activities has a strong and negative effect on household use probability.

In the Logit model, a farmer who used the direct seeding is considered to be user of traditional CA. Therefore, in a discrete utilization, a farm household has either used CA local technology or has not used. Dependent variable is either user or non-user. In order to explain this binary variable, it is necessary to construct a model that relates the dependent variable to a vector of independent variables. The logit model was employed in this study to estimate the effects of the hypothesized independent variables on the use probability of CA. 
Table 5: Logit model results of household use probability

\begin{tabular}{|c|c|c|}
\hline Use probability & Coefficient & Standard Error \\
\hline Livestock holding & $0.24 * * *$ & 0.08 \\
\hline Age & 0.004 & 0.04 \\
\hline Farm labor & $1.32 * * *$ & 0.51 \\
\hline Education level & -0.02 & 0.09 \\
\hline Participation in non-farm activities & $-1.77 *$ & 1.02 \\
\hline Access to credit & -0.68 & 0.96 \\
\hline Extension contact & -0.12 & 0.99 \\
\hline Participation in training & 0.71 & 0.62 \\
\hline Perception of traditional technology & $2.01 * *$ & 0.97 \\
\hline Information seeking behavior & 0.04 & 0.83 \\
\hline Remittance & 0.06 & 0.92 \\
\hline Distance to market & 0.49 & 0.30 \\
\hline Land holding & $3.85 * * *$ & 1.10 \\
\hline Constant & -27.05 & 7.76 \\
\hline Number of obs & & \\
\hline $\operatorname{LR} \operatorname{chi}^{2}(13)$ & & \\
\hline Prob $>\mathrm{chi}^{2}$ & & \\
\hline Log likelihood & & \\
\hline Pseudo $\mathrm{R}^{2}$ & & \\
\hline
\end{tabular}

Source: authors' computation

$* * *, * *$ and $*$ means significant at the $1 \%, 5 \%$ and $10 \%$ probability levels, respectively.

\subsection{Inferential Statistics}

A post estimation test for the goodness of fit after a logistic regression is crucial. In doing so, we have found a positive predictive value of 95.89 percent and a negative predictive value of 93.63 (see table 7 below) which is fit for our intending exercise.

Table 6: Goodness of fit test for logistic regression results

\begin{tabular}{ll}
\hline Particulars & Percentage \\
\hline Sensitivity & 95.89 \\
Specificity & 93.62 \\
Positive predictive value & 95.89 \\
Negative predictive value & 93.62 \\
\hline
\end{tabular}

Source: author's computation, 2015

\subsection{Identification of Conservation Agriculture Practices}

4.1. Awareness of indigenous knowledge in CA

Table 8 indicates that $86.3 \%$ of the respondents believe that indigenous knowledge can go a long way in helping conservation of natural resources. The local peoples conserve natural resource through practices of conservation agricultures. Among these the role of conservation agriculture is paramount in both crop and range land conservation in the district. On the contrary the $31.7 \%$ of the respondents saw nothing being offered by the traditional approach in natural resources conservation. This might be however caused by the lack of knowledge on indigenous knowledge systems.

Table 7: Assistance of the indigenous knowledge of CA in natural resources conservation

\begin{tabular}{|c|l|l|}
\hline Opinion & Number of respondents & \multicolumn{1}{|c|}{ Percentage } \\
\hline Yes & 82 & 68.3 \\
\hline No & 38 & 31.7 \\
\hline Do not know & 0 & 0 \\
\hline Total & 120 & 100 \\
\hline
\end{tabular}

Source: Author's computation, 2015

\subsection{Indigenous management practices of Conservation Agriculture}

Under this part based on the key informants' response the indigenous practices of conservation agriculture that practiced in the area are discussed in detail. The local farmers used to practice continuous conservation agriculture which needs to be managed very differently in order to keep or increase yield on the field. Weeds, equipment, grazing land rotations, water, soil, disease, pests, and fertilizer management, are just many details of farming 
practices that change when switching to minimum tillage.

\section{The Traditional Farm implement}

According to the key informants interview Puar is the traditional farm implement used in the district over long generations in crop production activities. The name / puor/ is used in Nuer language. The respondents expressed that Puar is made of wooden stick and an iron blade at one end of the stick locally. The stick part is used for handling whereas the blade part is used for both digging hole for seeding and weeding. The indigenous peoples expressed the advantages of paur in that it can be handled with a single person of any aged active labor forces say it 10 or above 65 and also be it male or female without feeling inconvenience in handling. Besides this they expressed its various advantages for indigenous people in saving their crop production time and labor, and requires low market cost of input for crop production.

The study also showed the absence of mechanization and draft animals as the local peoples are not accustomed to this technologies.

\section{Land perpetration}

The study also showed local peoples' system of their crop field preparation especially maize and sorghum which is twice in the production season one in the month of March and April during rain cropping and the other time in the month of September and October by recession agriculture near the river. Indigenous people directly seed their crops without repeated soil disturbance. The respondents gave justification for the advantage of using minimum tillage for its tendency in reducing water lodging or over flooding of river during rainy season. Furthermore, they provide their evidence by comparing infiltration rate of bare or tilled land with that of vegetation covered during rainy or floody seasons as residence area is flood threatened. They say untilled or vegetation covered land has better infiltration to protect water lodging or flood than bare/tilled land.

According to the key respondents the land preparation process of the local community has got considerable understanding of direct seeding practices with béër (row seeding) and kamkícr (spacing) between plants. From the study the advantage of using spacing and row seeding are for the convenience of crop management practices such as hand or paur weeding, intercropping of pumpkin/ beans with and maize and sorghum and also for harvesting purposes.

The survey result also showed the challenging situations in sowing rating of seed per hole, as the average rate of seeds per hole can reach up to 4-5. They say this amount of seed rate is maximum and reduces productivity of crop but this is done for the sake of increasing the chance of crop growth in fear of insect attack. The other showed challenge of land preparation is the shallow depth of rooting plant during sowing which causes frequent fall of crop during occurrence of heavy wind and rain.

\section{Fertilization of soil}

From the study the application of both organic and chemical fertilizers are not recognized to the local Nuer farming community of the district. Instead, according to the result of the interview local community applies direct seeding of crops with the seed of beans as pieth kecl (intercropping), but in the same hole with the main crop for the sake of its tendency of fertilization of soil.

From the study the unpracticed farm yard manure as fertilizer is the other challenge of fertilization as the area is known with its large number of livestock population.

\section{Crop rotation/leave for free practices}

According to the key respondents the type of shifting is the movement of Nuer people with their livestock to near river during dry season and to the upper land during rainy season is noted by local people as management strategy of their grazing land resources. They traditionally well know that long time stay at one point causes over grazing of range land and compaction of soil structure. In turn compaction of soil in turn destroys the soil structure for production of crops and range land. On the other side this also decreases the soil infiltration rate, and this in turn, maximizes water logging/flooding which further hinders soil productivity for both their crop and livestock.

From the study results the area is dominated by mono culturing (growth of only one type of crops like maize and sometimes sorghum with the small scale of tobacco) or absence of crop rotation and diversification which is the most challenging issue to be improved with respect to conservation agriculture.

\section{Soil cover crops/crop residues/mulching /}

The study revealed that the absence of utilization of locally adapted permanent or temporary cover crops are not practiced by the local farmers for soil organic matter developments such as source of nutrients, protection to erosions and high temperature which would be the challenge of indigenous farmers as they do not allow crop residues to left on the field rather they burn the residues in fear of transmittable pest and diseases to the next season cropping. In doing so, the local people protect their crops from the eggs and larvae of pests and diseases by catching fire on the residues of crops. Even they indigenously practice the growth of elephant grass by catching fire during the dry season. Burning grass is indigenously recognized by Nuer pastoralists as a means of favoring the growth of new cultivar from their roots which might be also other challenge from the context of conservation agriculture. Disease and pest protection

According to the key respondents of the study the average rate of seeding of crops used by local farmers can reach 
up to 4 to 5 seeds per hole. The study revealed that local farmers increase the number of seeds per hole for the sake of increasing the chance of seeds to germinate in reducing the chance of the seed be eaten by pests. It reveals also crop disease is indigenously protected by burning the crop residues after harvest, in fear of transmittable pest and diseases to the next cropping, so that the eggs and larvae of pests/vectors would be seized from transmission.

\section{Soil moisture content:}

According to the study indigenous farmers kept soil moisture with minimum tillage which increases infiltration rate, and decreases water lodging and run off or erosion. As the area is drought threatened accompanied with high temperature where annual average temperature reaches 35 degree centigrade. They also well recognized that minimum tillage reduces evaporation as it increases the rate of infiltration of water; this will further increase ground water table and soil moisture content. The other indigenous farming practice identified by study is utilization of recession agriculture which is the production of crops near the river side or basins. River side supports the local people's livelihood in both crop production and livestock production and fishing practices. The presence of moist fertile soil benefits farmers' crop production and succulent pasture growth for their livestock.

\section{Weeding}

The study identified the growth of weed which is the most challenging practice for local community as the study area is suitable (high temperature) for rapid growth of weeds after rains. Especially the growth of savanna grass land (elephant grass) or Sudan grass is paramount in covering the crop field. It was also revealed that uses of herbicides are not practiced in the area, therefore; protection of weed infestation is traditionally used by hand weeding using puar. The study also revealed indigenous community's growth of pumpkin under maize as intercropping so as to suppress weed growths in the crop.

\section{CONCLUSION AND RECOMMENDATION}

The empirical findings provide important messages for policy makers. They provide evidence that indigenous knowledge played a key role in conserving agriculture. As indicated earlier, the conservation agriculture has a strong positive relationship with livestock holding, land holding, farm labor and perception of traditional technology and strong negative relationship with participation in non-farm activities. This suggests that policy makers can scale up the use of minimum tillage by facilitating a medium for knowledge transfer from elders to youths as age is positively correlated with livestock holding, land holding and farm labor as well as minimum tillage; by diffusing the importance of minimum tillage and by creating awareness about the benefits of diversifying economic activities to split risks by using their resource abundance and endowment advantages.

At last, we emphasize the need for additional research to identify the role of indigenous knowledge on other dimensions of conservation agriculture in addition to the one investigated here. Moreover, future research should also collect qualitative data in addition to the quantitative one to provide further insight on the role of indigenous knowledge and draw context-specific lessons to improve management in conservation agriculture. Further research using much larger sample size and in different locations should be conducted to gain more insight into the role of indigenous knowledge in conservation agriculture. And finally, recommends that local knowledge of conservation tillage should be preserved in the study area through screening and documentation.

\section{REFERENCE}

A., Pisante, M., de Moraes Sà, J. (2012), Soil organic carbon accumulation and greenhouse gas emission reductions from Conservation Agriculture: A literature review. Integrated Crop Management Vol. 16, FAO, Rome, Italy. $89 \mathrm{pp}$.

Central Statistical Agency (CSA), Demographic and Health Survey of Ethiopia, AddisAbaba,

Chilot Yirga, B.I. Shapiro, and Mulate Demeke. 1996. Factors influencing adoption of new technologies in Wolmera and Addis Alem Areas of Ethiopia. Ethiopian Journal of Agricultural Economics. Vol. 1. p63-84. Agricultural Economic Society of Ethiopia Addis Ababa, Ethiopia.

Cosoleto, I(2010) The population of Ethiopia: ethnic, linguistic and religious divisions, in Fact Sheet: Ethiopia, University of Oslo

Erivin, C. A., and, D.C. Ervin,1982. Factors affecting the use of conservation practices: Hypothesis, Evidences and Policy Implications. Land Economics, 58(3): 97-107.

FAO (2009). Scaling-up Conservation Agriculture in Africa: Strategy and Approaches. The FAO Sub regional Office for Eastern Africa.

FAO (2011a), Save and Grow, a policymaker's guide to sustainable intensification of smallholder crop production, Food and Agriculture Organization of the United Nations, Rome. $116 \mathrm{pp}$.

FAO (2011b), What is Conservation Agricutlure? FAO CA website (http://www.fao.org/ag/ca/1a.html), FAO, Rome.

FAO 1998a. The Soil and Terrain Data Base for north-eastern Africa. Land and Water Digital

FAO, 2001. The economics of conservation agriculture. FAO Corporate Document Repository. Rome, Italy.

Feder,G., T. Onchan, Y. Chlam and L.C.Hong, 1988. Land policies and farm productivity 
Fowler, R. and Rockstrom, J. (2001). Conservation tillage for sustainable agriculture: An agrarian revolution gathers momentum in Africa. Soil and Tillage Research: Issue 61, Pages 93-107.

Friedrich, T., Kassam, A. and Shaxson, F. (2008). Conservation Agriculture (CA). Agricultural Technologies for Developing Countries, Annex 2. European Technology Assessment Group, FAO, Rome.

Gambela Peoples' Regional State, Bureau of Finance and Economic Development (BoFED), Situational Analysis of Agricultural Development in Gambela Region, Gambela, 2006. (Unpublished internal document)

Gambela Peoples‘ Regional State, Bureau of Finance and Economic Development

(BoFED), Report on Consultation Meeting of the Performance of Sustainable Development \& Poverty Reduction (SDPRP-I -2002/03-2004/05) held on July 5-6/2005, Gambela, 2005.

Habtemariam Abate, 2004. The comparative Influence of Intervening variable in the adoption

Hailemariam Behailu ,Mulugeta,Tsedal,Ali Jemal ,Galuak Katckos,Riek Weshik, Gezachew Asere, Tesfay Haile Asefaw banjo, Zelalem Wasihun,Umod Umode,2011 Action plan for Adaptation for Adaptation to climate change national Regional state worwdas

IIRR, 1998. Sustainable agriculture Extension manual for Eastern and Southern Africa.International Institute of Rural Reconstruction, Nairobi, Kenya. International Agricultural Development, pp 8-10, 13 (4)

IPCC (2007), Climate Change; Fourth Assessment report of the Intergovernmental Panel on Climate Change, Cambridge University Press.

Kidane Gebremariam, 2001. Factors influencing the adoption of new wheat verities, in Tigray, Ethiopia: the case of Hawizen district. An MSc Thesis Presented to the School of Graduate tudies of Alemaya University.164p.

Kolawole, O.D (2001) Local Knowledge Utilization and Sustainable Development in 21st Century, Indigenous Knowledge and Development Monitor 9-3 (4), Nov 2001.

Matsumoto, T. 2004. Evaluation of the Sasakawa Global 2000 Program in Ethiopia, 1992-2002. Sasakawa Africa Association.

Mekonnen Sime, 2007. Assessment of Factors Influencing Adoption of Integrated Striga

Mesfin T, Abebe G, Al-Tawaha ARM 2005 Effect of reduced tillage and crop residue ground cover on yield and water use efficiency of sorghum (Sorghum bicolor (L.) Moench) under semiarid conditions of Ethiopia. World Journal of Agricultural Sciences 1, 152-of Maize and Dairy Farmers in Shashemene and Debrezieit, Ethiopia. PhD Thesis, University of Pretoria.

Preston Sullivan (2004). "Sustainable Soil Management". Attra.ncat.org. Retrieved 2010-05-09.

Pretty, J., Toulmin, C. and Williams, S. (2011). Sustainable intensification in African agriculture. International Journal of Agricultural Sustainability: Issue 9, Pages 5-24.

Reijntjes C.(ed.) (2004) Bridging local knowledge and global science, COMPAS Magazine, pp 41-43, Sept, 2004. st Century, Indigenous Knowledge and Development Monitor 9-3 (4), Nov 2001.

Samson Abay, 2008. Floods and Health in Gambella region, Ethiopia: An Assessment of the strength and weakness of the coping mechanism. M.Sc. Thesis submitted to Lund University Centre for Sustainability Studies LUCSUS, LUND UNIVERSITY. LUND, SWEDEN. Samson_wakuma@yahoo.com

Tesfaye Beshah, 2003. Understanding farmers: Explaining soil and water conservation in Konso, Wolaita and Wollo, Ethiopia. Tropical Recourse Management Papers, No 41.Ph.D Dissertation. Wageningen University, Netherlands.

Tesfaye Lemma, 2003. Livelihood strategies in the context of population pressure: A case study in the Hararghe highlands, Eastern Ethiopia. Ph.D dissertation. University of Pretoria.

Tesfaye Zegeye and Alemu Haile, 2001. Adoption of improved maize technologies and inorganic fertilizer in north western Ethiopia. Ethiopian Agricultural Research Organization(EARO), research report no. 40. A.A, Ethiopia.p 1-52.Thailand. Johons Hopkins University press. Baltimore, M.D.

Warren,D.M., and Rajasekaran, B (1993) technologies in Wolmera and Addis Alem Areas of Ethiopia. J. Ethiopian Agricultural economics. 1:63-83 Putting Local Knowledge to Good Use, 